an oral Janus kinase inhibitor for the treatment of RA. Live zoster vaccine (LZV) has shown $70 \%$ efficacy in immunocompetent adults aged $50-59$ years and $51 \%$ efficacy in those aged $\geq 60$ years. $^{2}$ We previously reported that pts with RA on background methotrexate who started 3 months of treatment with tofacitinib after LZV had similar varicella zoster virus (VZV)-specific immunity to placebo (PBO) pts, and their VZV immunity at Week 6 post-vaccination was comparable with healthy individuals aged $\geq 50$ years. ${ }^{3}$

Objectives: To evaluate the long-term effectiveness of $L Z V$ in pts with $R A$ via the incidence of $\mathrm{HZ}$ after treatment with tofacitinib for up to 27 months.

Methods: Data were analysed from a prior cohort of pts $(n=100)$ given LZV and then randomised 2-3 weeks later to tofacitinib $5 \mathrm{mg}$ twice daily (BID) or PBO for 12 weeks (A3921237 [NCT02147587]). At 14 weeks post-vaccination, pts joining the long-term extension (LTE) study ORAL Sequel (NCT00413699; study ongoing; database not locked) initiated open-label treatment with tofacitinib 5 or $10 \mathrm{mg}$ BID. The incidence of $\mathrm{HZ}$ post-vaccination after tofacitinib exposure up to 27 months (based on an extended follow-up beyond January 2016 data snapshot) was evaluated. Among HZ cases, we analysed measures of VZV-specific immunity with average immunity after LZV.

Results: 112 pts were randomised to PBO $(n=57)$ or tofacitinib $5 \mathrm{mg} \mathrm{BID}$ $(n=55) .100$ pts continued to receive tofacitinib in ORAL Sequel. Five cases (not adjudicated) of HZ occurred (\#1: 202 days [219 days post-LZV], \#2: 267 days [281 days post-LZV], \#3: 702 days [748 days post-LZV], \#4: 699 days [741 days post-LZV], \#5: 446 days [544 days post-LZV] after initiation of tofacitinib. Cases \#1, \#2, \#3 and \#4 were monodermatomal; \#5 involved 5 dermatomes. All cases resolved with treatment. Cases \#1, \#4 and \#5 had undetectable ELISPOT measures at baseline and Week 6 post-vaccination, indicating a lack of VZV-specific immunity. Cases \#2 and \#3 responded adequately to vaccination by both immunoglobulin $\mathrm{G}(\mathrm{lgG})$ and ELISPOT measures, but had lower than average VZV IgG levels, both at baseline and at Week 6. (Table).

\begin{tabular}{|c|c|c|c|c|c|c|}
\hline \multicolumn{7}{|l|}{ Table. VZV ELISPOT and IgG levels } \\
\hline & \begin{tabular}{|c|} 
Case \#1 \\
(HZ \\
219 days \\
after zoster \\
vaccine)
\end{tabular} & $\begin{array}{c}\text { Case \#2 } \\
\text { (HZ } \\
281 \text { days } \\
\text { after zoster } \\
\text { vaccine) }\end{array}$ & $\begin{array}{c}\text { Case \#3 } \\
\text { (HZ } \\
748 \text { days } \\
\text { after zoster } \\
\text { vaccine) }\end{array}$ & $\begin{array}{c}\text { Case \#4 } \\
\text { (HZ } \\
741 \text { days } \\
\text { affer zoster } \\
\text { vaccine) }\end{array}$ & \begin{tabular}{|c|} 
Case \#5 \\
(HZ \\
544 days \\
after zoster \\
vaccine)
\end{tabular} & 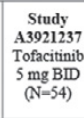 \\
\hline $\begin{array}{l}\text { VZV IFNy ELISPOT at baseline } \\
\text { (SFCs/10 } \mathrm{PBMCS} \text { ) }\end{array}$ & \begin{tabular}{|l}
25 (LOD) \\
\end{tabular} & 41 & 25 (LOD) & 25 (LOD) & 25 (LOD) & 48 \\
\hline $\begin{array}{l}\text { VZV IFN ELISPOT at Week } 6 \\
\text { (SFCs } 10^{\circ} \text { PBMCs) }\end{array}$ & \begin{tabular}{|l|l}
25 (LOD) \\
\end{tabular} & 76 & 51 & 25 (LOD) & 25 (LOD) & 70 \\
\hline $\begin{array}{l}\text { Change from baseline in VZV ELISPOT at } \\
\text { Week } 6 \text { (SFC fold-rise; } \mathrm{SFCS} / 10^{6} \mathrm{PBMCS} \text { ) }\end{array}$ & 1.00 & 1.85 & 2.04 & 1.00 & 1.00 & 1.50 \\
\hline $\begin{array}{l}\text { VZV IgG titer at baseline } \\
\text { (gpELISA units/mL) }\end{array}$ & 224 & 37 & 97 & 237 & 208 & 201 \\
\hline $\begin{array}{l}\text { VZV IgG titer at Week } 6 \\
\text { (gpELISA units/mL) }\end{array}$ & 444 & 71 & 187 & 232 & 223 & 403 \\
\hline $\begin{array}{l}\text { Change from baseline in VZV IgG titer at } \\
\text { Week 6 (fold-rise; ; } 2 \text { DLISA units/inL) }\end{array}$ & 1.98 & 1.92 & 1.93 & 0.98 & 1.07 & 2.11 \\
\hline
\end{tabular}

Individual values shown for Cases $\# 1-\# 5$, mean values shown for Study A3921237.

One patient who lacked pre-existing varicella immunity developed disseminated primary varicella from the vaccine strain 16 days post-vaccination (reported previously'). This case was excluded from calculations for $\mathrm{HZ}$

BID, twice daily, HZ, herpes zoster, IFNy, interferon gamma; IgG, immunoglobulin G; LOD, limit of detection;

PBMC, peripheral blood mononuclear cell; SFCs, spot-forming cells; VZV, varicella zoster virus

Conclusions: LZV prior to treatment with tofacitinib is effective at boosting IgG levels and cell-mediated immunity towards VZV. No pts who developed both strong cell-mediated and humoral immunity against VZV developed $\mathrm{HZ}$. Of the 5 pts who developed $\mathrm{HZ}, 3$ did not have any cell-mediated response and 2 had a low humoral response.

References:

[1] Singh JA et al. Arthritis Care Res (Hoboken) 2016; 68: 1-25.

[2] Hales CM et al. MMWR Morb Mortal Wkly Rep 2014; 63: 729-731.

[3] Winthrop K et al. Arthritis Rheumatol 2015; 67: Abstract 12L.

Acknowledgements: This study was sponsored by Pfizer Inc. The authors would like to acknowledge Lisa McNeil. Editorial support was provided by K Haines and $\mathrm{C}$ Evans of $\mathrm{CMC}$ and was funded by Pfizer Inc.

Disclosure of Interest: K. Winthrop Grant/research support from: Bristol-Myers Squibb, Pfizer Inc, Consultant for: AbbVie, Amgen, Bristol-Myers Squibb, Eli Lilly, Galapagos, Pfizer Inc, UCB, A. Wouters Shareholder of: Pfizer Inc, Employee of: Pfizer Inc, E. Choy Grant/research support from: Pfizer Inc, Consultant for: Pfizer Inc, Speakers bureau: Pfizer Inc, C. Nduaka Shareholder of: Pfizer Inc, Employee of: Pfizer Inc, P. Biswas Shareholder of: Pfizer Inc, Employee of: Pfizer Inc, L. Wang Shareholder of: Pfizer Inc, Employee of: Pfizer Inc, J. Hodge Shareholder of: Pfizer Inc, Employee of: Pfizer Inc, I. Lazariciu Consultant for: Pfizer Inc, Employee of: Quintiles, K. Soma Shareholder of: Pfizer Inc, Employee of: Pfizer Inc, C. Mojcik Shareholder of: Pfizer Inc, Employee of: Pfizer Inc, W. F. Rigby Grant/research support from: Amgen, Pfizer Inc, Roche, Consultant for: Bristol-Myers Squibb, Eli Lilly, Pfizer Inc, Roche

DOI: 10.1136/annrheumdis-2017-eular.2437

\section{LB0003 TOFACITINIB WITH AND WITHOUT METHOTREXATE VERSUS ADALIMUMAB WITH METHOTREXATE FOR THE TREATMENT OF RHEUMATOID ARTHRITIS: RESULTS FROM ORAL STRATEGY, A PHASE 3B/4 RANDOMISED TRIAL}

R. Fleischmann ${ }^{1}$, E. Mysler ${ }^{2}$, S. Hall ${ }^{3}$, A. Kivitz ${ }^{4}$, R. Moots ${ }^{5}$, Z. Luo ${ }^{6}$, S. Tatulych ${ }^{7}$, R. DeMasi ${ }^{8}$, K. Soma $^{7}$, R. Zhang ${ }^{9}$, L. Takiya ${ }^{8}$, C. Mojcik ${ }^{9}$, S. Krishnaswami ${ }^{7}$, S. Menon ${ }^{7}$, J. Smolen ${ }^{10} .{ }^{1}$ Metroplex Clinical Research Center and University of Texas Southwestern Medical Center, Dallas, TX, United States; ${ }^{2}$ Organización Médica de Investigación, Buenos Aires, Argentina; ${ }^{3}$ Department of Medicine, Monash University, Cabrini Health, Melbourne, Australia; ${ }^{4}$ Altoona Center for Clinical Research, Duncansville, PA, United States; 5 Institute of Ageing and Chronic Disease, University of Liverpool, Liverpool, United Kingdom; ${ }^{6}$ Pfizer Inc, Shanghai, China; ${ }^{7}$ Pfizer Inc, Groton, CT; ${ }^{8}$ Pfizer Inc, Collegeville, PA; ${ }^{9}$ Pfizer Inc, New York, NY, United States; ${ }^{10}$ Medical University of Vienna, Vienna, Austria

Background: Tofacitinib is an oral JAK inhibitor for the treatment of RA. There is no direct comparison of tofacitinib monotherapy vs tofacitinib +MTX in MTX inadequate responders (IR) and limited data comparing tofacitinib $( \pm M T X)$ vs adalimumab (ADA) +MTX in patients (pts) with RA.

Objectives: To compare efficacy and safety of tofacitinib monotherapy, tofacitinib+MTX, and ADA+MTX in a head-to-head, non-inferiority trial in MTX-IR pts. Methods: In this randomised, triple-dummy, active-controlled, 1-year, Phase 3b/4 trial (ORAL Strategy; NCT02187055), pts had active RA ( $>4$ tender/painful joints on motion and $\geq 4$ swollen joints [28-joint count] at baseline [BL]) inadequately controlled with MTX. Pts were randomised $1: 1: 1$ to receive tofacitinib $5 \mathrm{mg}$ twice daily ( $5 \mathrm{mg}$ mono BID), tofacitinib $5 \mathrm{mg}$ BID +MTX (5 mg BID+MTX) or subcutaneous ADA $40 \mathrm{mg}$ every other week +MTX (ADA+MTX); MTX dose: $15-25 \mathrm{mg} / \mathrm{wk}$. The primary endpoint was ACR50 at Month (Mo) 6 . Non-inferiority between treatments was declared if the lower bound of $98.34 \%$ two-sided confidence intervals of the difference of ACR50 response at Mo 6 was larger than $-13 \%$ (based on meta analysis of ADA trials ${ }^{1}$ ), and superiority if it was larger than $0 \%$. Other endpoints included: ACR20/50/70 and least-squares mean changes from BL in SDAl, DAS28-4(ESR) and HAQ-DI at Mos 6 and 12. Safety was assessed throughout the trial.

Results: 1146 pts were randomised and treated $(5 \mathrm{mg}$ mono BID: $n=384$; $5 \mathrm{mg}$ BID+MTX: $\mathrm{n}=376$; $A D A+M T X: n=386$ ). Demographics and $B L$ disease characteristics were similar across groups. Most pts were female (82.7-83.1\%), white $(75.9-77.1 \%)$, with a mean age of $49.7-50.7$ years, median disease duration of 5.4-6.1 years and mean HAQ-DI score of 1.6. Across groups, $80.2-81.6 \%$ of pts completed the study. ACR50 response rate at Mo 6 was $38.3 \%$ for $5 \mathrm{mg}$ mono BID, $46.0 \%$ for $5 \mathrm{mg} \mathrm{BID}+\mathrm{MTX}$ and $43.8 \%$ for ADA+MTX. Non-inferiority was demonstrated for $5 \mathrm{mg} B I D+M T X$ vs ADA+MTX $(P<0.0001)$ but not for $5 \mathrm{mg}$ mono BID vs ADA+MTX ( $P=0.0512)$ or $5 \mathrm{mg}$ mono BID vs $5 \mathrm{mg}$ BID+MTX $(P=0.2101)$ which, although numerically different, were not statistically different (Figure). Tofacitinib monotherapy achieved the efficacy expected of an effective immunomodulator in this pt population. Secondary efficacy analyses were generally consistent with the primary analysis (Table). Adverse event $(A E)$, serious $A E$ and discontinuation due to $A E$ rates were generally clinically similar across groups, though numerically fewer pts had increased alanine aminotransferase with $5 \mathrm{mg}$ mono BID vs $5 \mathrm{mg}$ BID+MTX or ADA+MTX.

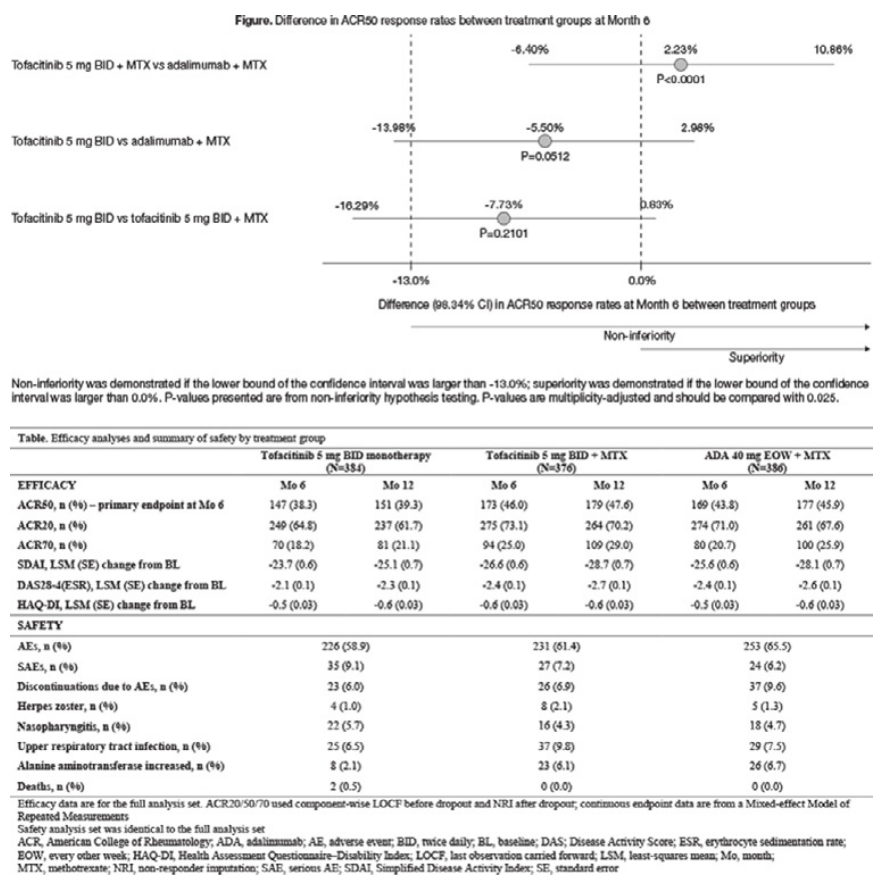

Conclusions: Tofacitinib $5 \mathrm{mg}$ BID+MTX was as effective as ADA+MTX in 
MTX-IR pts with RA. However, clinical outcomes of all 3 regimens, including tofacitinib $5 \mathrm{mg}$ BID monotherapy, were comparable. There were no new or unexpected safety issues.

\section{References:}

[1] Machado et al. Rev Bras Reumatol 2013;53:419-430.

Acknowledgements: This study was funded by Pfizer Inc. Editorial support provided by $\mathrm{D}$ Binks of $\mathrm{CMC}$.

Disclosure of Interest: R. Fleischmann Grant/research support from: Abbott, Amgen, Astellas, Bristol-Myers Squibb, Boehringer Ingelheim, Celgene, Genentech, Eli Lilly, Janssen, Novartis, Pfizer Inc, Regeneron Pharmaceuticals Inc., Sanofi Aventis, Roche, UCB, Consultant for: Abbott, Akros, Amgen, Bristol-Myers Squibb, Celgene, Genentech, Eli Lilly, Janssen, Novartis, Pfizer Inc, Sanofi Aventis, UCB, E. Mysler Grant/research support from: AbbVie, Bristol-Myers Squibb, Eli Lilly, Janssen, Medimmune, Pfizer Inc and Roche, Consultant for: AbbVie, BristolMyers Squibb, Eli Lilly, Janssen, Medimmune, Pfizer Inc and Roche, Speakers bureau: AbbVie, Bristol-Myers Squibb, Eli Lilly, Janssen, Medimmune, Pfizer Inc and Roche, S. Hall Consultant for: Pfizer Inc, Celgene, Roche, AbbVie, Eli Lilly, Janssen, A. Kivitz Grant/research support from: AbbVie, Amgen, Bristol-Myers Squibb, Genentech and Pfizer Inc, Consultant for: AbbVie, Amgen, Bristol-Myers Squibb, Genentech and Pfizer Inc, Speakers bureau: AbbVie, Amgen, BristolMyers Squibb, Genentech, and Pfizer Inc, R. Moots Grant/research support from: Biogen, Bristol-Myers Squibb, Chugai, Novartis, Pfizer, Roche, Sandoz, UCB Pharma, Consultant for: Biogen, Bristol-Myers Squibb, Chugai, Novartis, Pfizer, Roche, Sandoz, UCB Pharma, Speakers bureau: Biogen, Bristol-Myers Squibb, Chugai, Novartis, Pfizer, Roche, Sandoz, UCB Pharma, Z. Luo Shareholder of: Pfizer Inc, Employee of: Pfizer Inc, S. Tatulych Shareholder of: Pfizer Inc, Employee of: Pfizer Inc, R. DeMasi Shareholder of: Pfizer Inc, Employee of: Pfizer Inc, K. Soma Shareholder of: Pfizer Inc, Employee of: Pfizer Inc, R. Zhang Shareholder of: Pfizer Inc, Employee of: Pfizer Inc, L. Takiya Shareholder of: Pfizer Inc, Employee of: Pfizer Inc, C. Mojcik Shareholder of: Pfizer Inc, Employee of: Pfizer Inc, S. Krishnaswami Shareholder of: Pfizer Inc, Employee of: Pfizer Inc, S. Menon Shareholder of: Pfizer Inc, Employee of: Pfizer Inc, J. Smolen Grant/research support from: AbbVie, Janssen, Lilly, MSD, Pfizer Inc, and Roche, Consultant for: AbbVie, Amgen, AstraZeneca, Astro, Celgene, Celtrion, Glaxo, ILTOO, Janssen, Lilly, Medlmmune, MSD, Novartis-Sandoz, Pfizer Inc, Roche, Samsung, Sanofi, and UCB, Speakers bureau: AbbVie, Amgen, AstraZeneca, Astro, Celgene, Celtrion, Glaxo, ILTOO, Janssen, Lilly, Medlmmune, MSD, Novartis-Sandoz, Pfizer Inc, Roche, Samsung, Sanofi, and UCB

DOI: 10.1136/annrheumdis-2017-eular.7113

\section{FRIDAY, 16 JUNE 2017 \\ New treatments in SLE, Sjögren's and APS}

\section{OP0231 THE EFFECT OF "TRIPLE THERAPY" WITH ANTICOAGULATION PLUS CORTICOSTEROIDS PLUS PLASMA EXCHANGE AND/OR INTRAVENOUS IMMUNOGLOBULINS ON THE MORTALITY OF CATASTROPHIC ANTIPHOSPHOLIPID SYNDROME (CAPS) PATIENTS}

I. Rodríguez-Pintó ${ }^{1}$, G. Espinosa ${ }^{1}$, D. Erkan ${ }^{2}$, Y. Shoenfeld ${ }^{3}$, R. Cervera ${ }^{1}$ on behalf of CAPS Registry Project Group (European Forum on Antiphospholipid Antibodies). ${ }^{1}$ Department of Autoinmune Disease, Hospital Clínic, Barcelona, Spain; ${ }^{2}$ Barbara Volcker Center for Women and Rheumatic Disease, Hospital for Special Surgery, New York, United States; ${ }^{3}$ Zabludowicz Center for Autoimmune Diseases, Sheba Medical Center, Tel Aviv, Israel

Background: Triple therapy (anticoagulation plus corticosteroids plus plasma exchange and/or intravenous immunoglobulins) is empirically prescribed for the management of catastrophic antiphospholipid syndrome (CAPS). However, previous analyses have been inconsistent regarding the beneficial effect of triple therapy on patients' survival.

Objectives: The objective of this study was to assess the effect that triple therapy has on the mortality risk of CAPS patients.

Methods: In a cohort including 525 episodes of CAPS (CAPS Registry), we evaluated the relationship between triple therapy and mortality. Patients were grouped in three based on their treatments: a) triple therapy (anticoagulation plus corticosteroids plus plasma exchange and/or intravenous immunoglobulins); b) drugs included in the triple therapy but in different combinations; c) none of the treatments included in the triple therapy. The primary endpoint was all-cause mortality. Multivariate logistic regression models were used to compare mortality risk between groups taking into account a set of possible confounding variables. Results: The "CAPS registry" cohort included 525 episodes of CAPS accounting for 502 patients. After excluding 38 episodes (7.2\%), a total of 487 episodes of CAPS accounting for 471 patients (mean age 38 years; $67.9 \%$ female; primary APS patients $68.8 \%$ ) were analyzed. Overall, $177(36.3 \%)$ patients died. Triple therapy was prescribed in 197 episodes $(40.5 \%)$, other combinations in 278 $(57.1 \%)$, and none of those treatments in 12 episodes $(2.5 \%)$. According to these three groups, mortality rate increased up to $27.9 \%, 40.6 \%$, and $75 \%$, respectively. Triple therapy was positively associated with a higher chance of survival when compared to non-treatment (adjusted odds ratio [OR]: 7.7 95\%; confidence interval [95CI] 2.0-29.7) or to treatment with other combinations of drugs included in the triple therapy (adjusted OR 6.8; $95 \mathrm{Cl} 1.7-26.9$ ). Triple therapy accounted for a $64 \%$ decrease of the risk of death in patients with CAPS that received this combination of drugs.

Conclusions: Triple therapy is independently associated to a higher survival rate among CAPS.

Acknowledgements: To the CAPS Registry Project Group (European Forum on Antiphospholipid Antibodies).

Disclosure of Interest: None declared

DOI: 10.1136/annrheumdis-2017-eular.3412

\section{OP0232 SUSTAINED SAFETY AND EFFICACY OVER 10 YEARS WITH BELIMUMAB (BEL) PLUS STANDARD SYSTEMIC LUPUS ERYTHEMATOSUS (SLE) THERAPY (SOC) IN PATIENTS WITH SLE}

D.J. Wallace $^{1}$, E.M. Ginzler ${ }^{2}$, J.T. Merrill ${ }^{3}$, R.A. Furie ${ }^{4}$, W. Stohl ${ }^{5}$,

W. Chatham ${ }^{6}$, A. Weinstein ${ }^{7}$, J. McKay ${ }^{8}$, W.J. McCune ${ }^{9}$, M. Petri ${ }^{10}$

J. Fettiplace ${ }^{11}$, D. Roth ${ }^{12}$, B. Ji ${ }^{13}$, A. Heath ${ }^{14} .{ }^{1}$ Cedars-Sinai Medical Center, Los Angeles; ${ }^{2}$ SUNY Downstate Medical Center, Brooklyn; ${ }^{3}$ Oklahoma Medical Research Foundation, Oklahoma City; ${ }^{4}$ Northwell Health, Great Neck;

${ }^{5}$ University of Southern California Keck School of Medicine, Los Angeles;

${ }^{6}$ University of Alabama at Birmingham, Birmingham; ${ }^{7}$ Washington Hospital Center, Washington DC: ${ }^{8}$ Oklahoma State University Center for Health Sciences, Tulsa: ${ }^{9}$ University of Michigan, Ann Arbor; ${ }^{10}$ Johns Hopkins University School of Medicine, Baltimore, United States; ${ }^{11}$ GSK (at the time of study), Uxbridge, United Kingdom; ${ }^{12}$ GSK, Philadelphia, United States; ${ }^{13}$ GSK, Uxbridge, United Kingdom; ${ }^{14}$ GSK, Raleigh-Durham, United States

Background: Preliminary safety and efficacy data from the Phase II BEL open-label extension study (LBSL02; NCT00071487) have been reported.

Objectives: Here we present the final 10-year data.

Methods: This was a multicentre, open-label, continuation trial (BEL112626; NCT00583362) of BEL + SoC in patients with a satisfactory response in the parent study. Patients received intravenous BEL $10 \mathrm{mg} / \mathrm{kg}$ every 4 weeks. Baseline was prior to the first ever dose of BEL.

Results: Of 298 patients in the continuation trial, 131 (44\%) remained at Year 10. Total BEL exposure was 2154 patient-years. Adverse events (AEs) remained stable or decreased (Table). Two deaths (pseudomonal lung infection; cytomegaloviral pneumonia) were possibly related to BEL. SLE Responder Index (SRI) response increased (Figure). A British Isles Lupus Assessment Group (BILAG) flare (1 new A/2 new B scores) occurred in $72.6 \%$ of patients and $41.9 \%$ had a severe flare (SLE Flare Index). Prednisone dose decreased from baseline to Year 10 (Table). Of patients receiving $>7.5 \mathrm{mg} /$ day baseline prednisone, $32.6 \%$

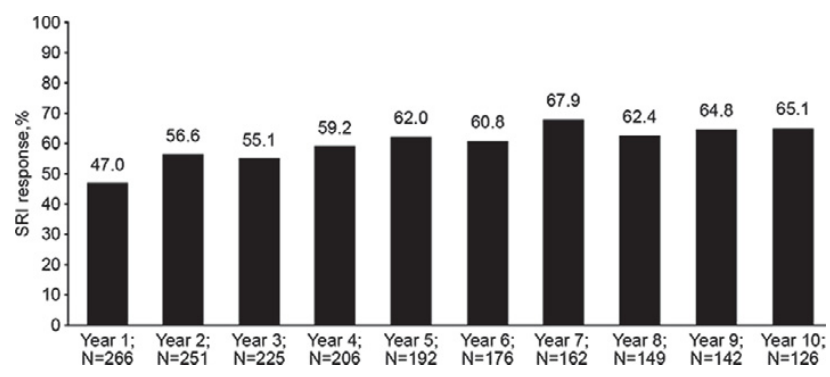

\begin{tabular}{|c|c|c|c|c|c|c|c|c|c|c|c|}
\hline & $\begin{array}{c}0-1 y \\
(N=296)\end{array}$ & $\begin{array}{c}1-2 y \\
(N=294)\end{array}$ & $\begin{array}{c}2-3 y \\
(N=276)\end{array}$ & $\begin{array}{c}3-4 y \\
(N=250)\end{array}$ & $\begin{array}{c}4-5 y \\
(N=223)\end{array}$ & $\begin{array}{c}5-6 y \\
(N=209)\end{array}$ & $\begin{array}{c}6-7 y \\
(N=192)\end{array}$ & $\begin{array}{c}7-8 y \\
(N=178)\end{array}$ & $\begin{array}{c}8-9 y \\
(N=169)\end{array}$ & $\begin{array}{c}9-10 y \\
(N=152)\end{array}$ & $\begin{array}{l}10-11 y \\
(N=131)\end{array}$ \\
\hline \multicolumn{12}{|l|}{ Incidence of $\geq 1 \mathrm{AE}, \mathrm{n}(\%)$} \\
\hline Overall & $291(98.3)$ & $283(96.3)$ & $260(94.2)$ & $239(95.6)$ & $203(91.0)$ & $190(90.9)$ & $182(94.8)$ & $162(91.0)$ & $157(92.9)$ & $137(90.1)$ & $105(80.2)$ \\
\hline Resulting in discontinuation & $2(0.7)$ & $3(1.0)$ & $3(1.1)$ & $7(2.8)$ & $5(2.2)$ & $6(2.9)$ & $6(3.1)$ & $1(0.6)$ & $3(1.8)$ & $5(3.3)$ & $2(1.5)$ \\
\hline Serious AE & $41(13.9)$ & $43(14.6)$ & $50(18.1)$ & $30(12.0)$ & $40(17.9)$ & $33(15.8)$ & $35(18.2)$ & $34(19.1)$ & $28(16.6)$ & $25(16.4)$ & $14(10.7)$ \\
\hline Serious infections/infestations & $11(3.7)$ & $13(4.4)$ & $9(3.3)$ & $9(3.6)$ & $6(2.7)$ & $6(2.9)$ & $12(6.3)$ & $10(5.6)$ & $8(4.7)$ & $5(3.3)$ & $5(3.8)$ \\
\hline \multirow[t]{2}{*}{ Death } & $1(0.3)$ & 0 & $1(0.4)$ & $1(0.4)$ & 0 & $1(0.5)$ & $2(1.0)$ & 0 & 0 & $1(0.7)$ & 0 \\
\hline & & $\mathrm{Y} 1$ & $\mathrm{Y} 2$ & Y3 & $\mathrm{Y} 4$ & $\mathrm{Y} 5$ & Y6 & Y7 & Y8 & Y9 & $\mathrm{Y} 10$ \\
\hline \multicolumn{12}{|l|}{ Prednisone } \\
\hline $\begin{array}{l}\text { median } \% \text { change from baselin } \\
\text { 25th, 75th percentile }(n)\end{array}$ & & $\begin{array}{c}-0.4 \\
-50.0,0(186)\end{array}$ & $\begin{array}{c}-25.0 \\
-74.2,0(172)\end{array}$ & $\begin{array}{c}-36.9 \\
-80.0,0(153)\end{array}$ & $\begin{array}{c}-50.0 \\
100.0,0(140)\end{array}$ & $\begin{array}{c}-48.3 \\
-100.0,0(128)\end{array}$ & $\begin{array}{l}-60.0 \\
0(115)\end{array}$ & $\begin{array}{c}-62.5 \\
-100.0,-10.7(105)\end{array}$ & $\begin{array}{c}-70.0 \\
-100.0,-1.6(94)\end{array}$ & $\begin{array}{c}-66.7 \\
-100.0,-0(91)\end{array}$ & $\begin{array}{c}-65.8 \\
-100.0,0(84)\end{array}$ \\
\hline
\end{tabular}

